\title{
Drying on the germination and vigor of Crataeva tapia L. seeds
}

\author{
Edna Ursulino Alves ${ }^{1}$ Sueli da Silva Santos-Moura ${ }^{*}$ Mácio Farias de Moura $^{2}$ \\ Rosemere dos Santos Silva ${ }^{1}$ Evio Alves Galindo ${ }^{3}$
}

${ }^{1}$ Centro de Ciências Agrárias (CCA), Universidade Federal da Paraíba (UFPB), 58397-000, Areia, PB, Brasil. E-mail: sssantosagro@hotmail.com. ${ }^{*}$ Corresponding author.

${ }^{2}$ Unidade Acadêmica de Garanhuns (UAG), Universidade Federal Rural de Pernambuco (UFRPE), Boa Vista, Graranhuns, PE, Brasil.

${ }^{3}$ Instituto Federal de Pernambuco (IFPE), Campus Ouricuri, Vila Quixada, Ouricuri, PE, Brasil.

\begin{abstract}
Crataeva tapia L. is a fruit native to the Brazilian savanna, the caatinga, and is used in the production of soft drinks and other beverages. Given the importance of this species and the lack of knowledge about its seeds, this research aimed to evaluate the physiological quality of C. tapia L. seeds subjected to different environments and drying periods. Seeds were dried for the following time periods: 0 (no drying), 24, 48, 72, 96, and 120 hours, in the laboratory environment $\left(25^{\circ} \mathrm{C}\right.$ and $\left.90 \% \mathrm{RH}\right)$ and in a greenhouse $\left(30^{\circ} \mathrm{C}\right.$ and $\left.80 \% \mathrm{RH}\right)$. After the drying period, seeds from each of the treatments were used for determining the water content, germination, and vigor (using tests for emergence, first count of germination and emergence, rate of germination and emergence, length, and seedling dry weight). The experimental design was completely randomized and a factorial $2 \times 6$ scheme (local environment $\times$ drying periods) was used with four replicate sets of seeds. The data were subjected to analysis of variance and polynomial regression using quadratic models. The germination and seed vigor reduced as the drying periods increased. For optimum results, the seeds of C. tapia L. must be dried in the laboratory for a period of 48 hours. In addition, their desiccation resistance was classified as intermediate.

Key words: Trapiá, native fruit, seed viability.
\end{abstract}

Secagem de sementes de Crataeva tapia L. sobre a germinação e vigor

RESUMO: Crataeva tapia L. é uma frutifera nativa da caatinga, cujos frutos são utilizados para a produção de refresco e bebida vinosa. Devido à importância da espécie e a inexistência de informações sobre suas sementes, objetivou-se avaliar a qualidade fisiológica das mesmas quando submetidas a diferentes ambientes e periodos de secagem. As sementes foram submetidas à secagem pelos seguintes períodos 0 (sem secagem), 24, 48, 72, 96 e 120 horas em ambiente de laboratório $\left(25^{\circ} \mathrm{C}\right.$ e $90 \%$ UR) e casa de vegetação (30 ${ }^{\circ} \mathrm{C}$ e $80 \%$ UR). Após cada período de secagem as sementes foram submetidas à determinação do teor de água e a testes de germinação e vigor (emergência, primeira contagem de germinação e de emergência, índice de velocidade de germinação e de emergência, comprimento e massa seca de plântulas). O delineamento experimental utilizado foi o inteiramente ao acaso, em esquema fatorial $2 \times 6$ (locais e períodos de secagem), em quatro repetições. Os dados foram submetidos à análise de variância e de regressão polinomial, utilizando os modelos linear e quadrático. A germinação e o vigor das sementes são reduzidos com a secagem, principalmente em casa de vegetação. As sementes de Crataeva tapia L. podem ser secas em ambiente de laboratório por um periodo de 48 horas e são classificadas como intermediárias.

Palavras-chave: Trapiá, frutifera nativa, viabilidade.

\section{INTRODUCTION}

Crataeva tapia $L$. belongs to the Capparaceae family, and is popularly known by the names trapiá, cabaceira, pau-de-alho, and tapiá, among others. It is native to Caatinga, and has a dense and rounded canopy that can reach up to $12 \mathrm{~m}$ in height. The fruits are globular, with an edible carnous pulp that is white in color, and are consumed as a part of refreshment drinks and vinosa. Such species also occurs in other formations of the Northeast and other regions from Pernambuco to Sao Paulo and Minas Gerais, with records in the Atlantic rain forest and the Pantanal of Mato Grosso (LORENZI, 2009).

The capacity of seeds to tolerate postharvest drying varies among different species. However, most species have seeds that are classified as orthodox, which can tolerate desiccation untill the water content reduces to $2-5 \%$, depending on the species. This tolerance is achieved by decreasing 
the rates of metabolism and respiration, which is advantageous for long-duration seed preservation at low temperatures without compromising their viability (FONSECA \& FREIRE, 2003).

Other species have seeds that are classified as intermediate, which tolerate desiccation till 10$13 \%$ water content, and exhibit a reduced viability at moisture levels lower than these (ROBERTS, 1973; HONG \& ELLIS, 1996). For recalcitrant seeds there is water content defined as critical, between 27 and $38 \%$ which underneath viability is reduced; there are also lethal water content between 12 and $22 \%$, related to the total loss of viability (NASCIMENTO et al., 2007).

Recently, the "all or nothing" idea of seed intolerance to dehydration has been replaced by a more quantitative factor, which suggested that recalcitrant seeds should be categorized by the minimum water content at which they can stay viable (REGO, 2012). WALTERS (2000) reported that there is a gradient of desiccation tolerance among seeds, ranging from intolerant (highly recalcitrant) to the most tolerant (classical orthodox), and the minimum water content varies according to the species.

Drying seeds, as well as contributing to the preservation of physiologic, enables the early harvest of the same, being primordial water content in determining the appropriate time of harvest, thus, several drying methods have been employed to assess the desiccation tolerance of seeds; among these, natural drying is the most widely used method; although, it is limited by weather, for example, when there are unfavorable conditions of relative humidity and temperature, or when there are large volumes of seeds, the drying of seeds can be hampered (GARCIA et al., 2004; CARVALHO, 2005).

As for C. tapia seed technology, studies exist related to the influence of water stress, salt, and temperature (GALINDO, 2010), substrates and temperatures (ALVES et al., 2012), light regimes and temperatures (GALINDO et al., 2012), and extraction of the mucilage in the germination and vigor of seeds (SANTOS-MOURA et al., 2014), but no research has been done on the dehydration tolerance of seeds.

Therefore, the objective of the present study was to evaluate dehydration tolerance in seeds of Crataeva tapia L. and change in the physiological quality of the seeds when they are subjected to drying in different environments.

\section{MATERIALS AND METHODS}

This research was conducted at the Laboratory of Seed Analysis (LSA) in the Department of
Plant and Environmental Sciences, a part of the Center of Agricultural Sciences at the Universidade Federal da Paraíba. Ripe fruits (characterized by yellowing) of Crataeva tapia L., were collected from 11 mother trees located in the town of Remigio-PB, and were sent to the LSA, where the manual processing of opening the fruits and extracting the seeds was carried out.

Prior to the drying, the freshly extracted seeds from the fruit (surrounded by a mass of mucilage) went through fermentation for 48 hours and were subsequently washed with running water, placed on paper towels, and dried in the laboratory $\left(25^{\circ} \mathrm{C}\right.$ and $\left.90 \% \mathrm{RH}\right)$ and greenhouse $\left(30^{\circ} \mathrm{C}\right.$ and $80 \%$ $\mathrm{RH}$ ) for one of the following periods: 0 (no drying), $24,48,72,96$, or 120 hours. They were then used for the determination of water content and other tests described below.

\section{Water content}

For this, we dried the samples in an oven at $105 \pm 3^{\circ} \mathrm{C}$ for 24 hours (BRASIL, 2009), and four replicate sets with 10 seeds each were used for each treatment. Results were expressed as a percentage.

\section{Germination test}

This test was conducted for four replicate sets of 25 seeds each per treatment. Samples were placed in a paper towel moistened with distilled water (equivalent to 2.5 times the weight of the dry substrate), then incubated at alternating temperatures of 20 and $30^{\circ} \mathrm{C}$ with eight hours of photoperiod as recommended by ALVES et al. (2012). Four replicate sets for each treatment were distributed over two moistened sheets of paper towel and; subsequently, covered with a third sheet of paper to roll them up. Rolls were packed in plastic bags to prevent loss of water by evaporation, and evaluations were performed daily, for 7 to 15 days after commencement of the test, to allow for germination stabilization of germination. Evaluations involved computing the proportion of normal seedlings, defined as those with primary root and developed shoots.

\section{Emergence test}

This test was carried out in greenhouse conditions, with four replicate sets of 25 seeds that were sown in plastic trays of dimensions $49 \times 33 \times 7 \mathrm{~cm}$, containing sand substrate sterilized at $120^{\circ} \mathrm{C}$ for two hours. During the test, humidity of the substrate was maintained through daily watering. Evaluations were made for 8 to 21 days since the test started, to allow emergence stabilization, criterion for which was the seedlings displayed a shoot above the substrate level. To 
calculate the emergence, we considered the data from a single count performed at 21 days, and results were expressed as a percentage of the total number of seeds.

First count of germination and emergence at the seventh and eighth days

They were made in conjunction with the germination and emergence tests, by counting the number of normal seedlings on the seventh and eighth day after sowing. It was considered as a criterion of normal seedlings those with root and shoot perfect for germination. The results were expressed as a percentage of the total number of seeds for shoot above the substrate level for the emergence.

\section{Germination and emergence speed index}

They were determined by daily counts of both number of seeds germinated and emerged seedlings, for 7 to 15 and 8 to 21 days after the commencement of tests, respectively. Indices were calculated according to the formula

$$
\text { IVE } \left.=\frac{E_{1}+E_{2}+\ldots+E_{n}}{N_{1}+N_{2}+\ldots+N_{n}}\right) \text {, proposed by MAGUIRE }
$$

(1962), where IVE $=$ emergence speed index, $\mathrm{E}_{\mathrm{n}}=$ number of normal seedlings emerging on the $\mathrm{n}^{\text {th }}$ day, and $\mathrm{N}_{\mathrm{n}}=$ number of days from sowing untill the $\mathrm{n}^{\text {th }}$ day.

\section{Length and seedling dry weight}

After the final count for germination and emergence tests, the normal seedlings from each replicate set were measured in length from the root to the stem apex, with the aid of a ruler graduated in centimeters, and results were expressed in $\mathrm{cm}$ seedling $^{-1}$. Seedlings were placed in paper bags and kept in an oven with air circulation at $65^{\circ} \mathrm{C}$ until a constant weight was achieved (which took approximately 48 hours). After this drying period, they were weighed on a scale accurate to $0.001 \mathrm{~g}$, and results were expressed in $\mathrm{g}_{\text {seedling }}{ }^{-1}$.

\section{Experimental design and statistical analysis}

Experimental design was completely randomized, and treatments were distributed in a $2 \times 6$ factorial scheme (environments and drying periods), with four replicates. The data were subjected to analysis of variance and polynomial regression using linear and quadratic models, and averages from the qualitative data were compared by Tukey's test at significance level $=0.05$.

\section{RESULTS AND DISCUSSION}

Water content of the Crataeva Tapia L. seeds reduced with increasing periods of desiccation, decreasing from 34.13 to $12.33 \%$ and from 33.04 to $11.47 \%$ after 48 hours of drying in a greenhouse environment and the laboratory environment, respectively (Figure 1). Drying of seeds for this species can be considered as slow, because a drying period of 48 hours was required to reach those water levels.

The proportion of water loss by C. tapia seeds during drying was similar in both environments, showing a pronounced loss in the first 48 hours (Table 1 and 2). Rapid loss of water early during the drying is possibly due to high initial water content in seeds (34\%). Reduction is slower after this initial period, with a slight increase observed at 96 hours in both environments. This is probably due to fluctuations in weather, which is a factor that limits the natural drying of seeds, making the entire process dependent on favorable conditions (CARVALHO, 2005), especially if seeds are hygroscopic and have the ability to adjust the water content according to the environmental conditions.

Similar to our results, SANTOS-MOURA et al. (2012) observed that the reduction in water content in the seeds of Tapirira guianensis Aublet. was more drastic in the initial stages of drying, and that the percentage loss gradually decreased with increasing drying period on a renewal and forced air circulation oven.

For Tapirira obtusa (Benth.) J. D. Mitchell seeds submitted to drying, water content reduced quickly from 50 to $10 \%$; however, the moisture loss varied with the place of origin (rocky area, closed area, or riparian area), being that seeds from Cerrado environment lost the water lost slowly and were more sensitive to dehydration (PEREIRA et al., 2012), indicating that depending on the environmental conditions, the seed characteristics can adapt and undergo changes in their responses.

Conversely, seeds of C. tapia that were not submitted for drying expressed a higher germination

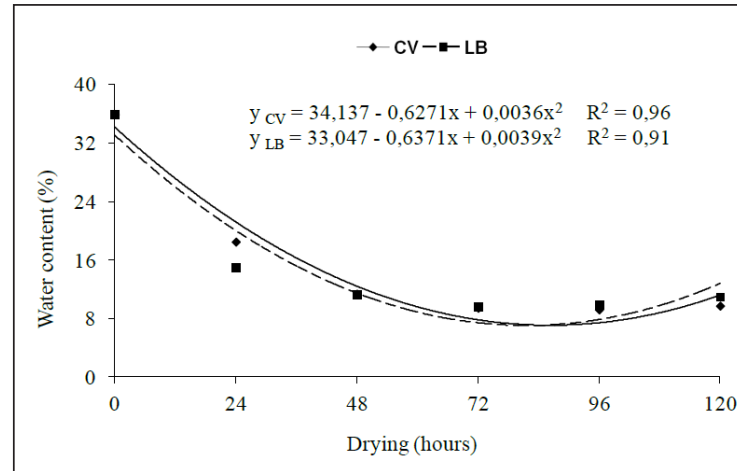

Figure 1 - Water content of Crataeva tapia L. seeds, dried in greenhouse (CV) and lab environment (LB). ${ }^{* *} \mathrm{p}<0.01$. 
Table 1 - Water content (TA), germination (G), speed indices of seed germination(IVG), first counts of germination (PC), length (COMP) and dry mass (MSP) of Crataeva tapia L. seedlings from germination tests after drying in greenhouse (CV) and lab environment (LB).

\begin{tabular}{|c|c|c|c|c|c|c|c|}
\hline \multirow{2}{*}{ Variables } & \multirow{2}{*}{ Drying environments } & \multicolumn{6}{|c|}{ 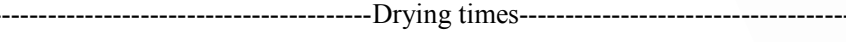 } \\
\hline & & 0 & 24 & 48 & 72 & 96 & 120 \\
\hline \multirow[b]{2}{*}{ TA $(\%)$} & $\mathrm{CV}$ & $35.9 \mathrm{a}$ & $18.5 \mathrm{a}$ & $11.4 \mathrm{a}$ & $9.4 \mathrm{a}$ & $9.2 \mathrm{~b}$ & $10.0 \mathrm{~b}$ \\
\hline & LB & $35.9 \mathrm{a}$ & $14.9 \mathrm{~b}$ & $11.3 \mathrm{a}$ & $9.6 \mathrm{a}$ & $10.0 \mathrm{a}$ & $10.9 \mathrm{a}$ \\
\hline \multirow[b]{2}{*}{$\mathrm{G}(\%)$} & $\mathrm{CV}$ & $94 a$ & $88 b$ & $80 \mathrm{~b}$ & $77 b$ & $75 b$ & $81 b$ \\
\hline & LB & $94 a$ & $93 a$ & $93 a$ & $94 a$ & $87 \mathrm{a}$ & $88 \mathrm{a}$ \\
\hline \multirow[b]{2}{*}{ IVG } & $\mathrm{CV}$ & $3.27 \mathrm{a}$ & $2.96 \mathrm{a}$ & $2.47 \mathrm{a}$ & $2.32 b$ & $2.19 b$ & $1.59 \mathrm{~b}$ \\
\hline & LB & $3.27 \mathrm{a}$ & $3.21 \mathrm{a}$ & $2.47 a$ & $3.40 \mathrm{a}$ & $3.10 \mathrm{a}$ & $2.87 \mathrm{a}$ \\
\hline \multirow[b]{2}{*}{$\mathrm{PC}$} & $\mathrm{CV}$ & $65 a$ & $52 b$ & $25 b$ & $29 b$ & $13 b$ & $12 \mathrm{a}$ \\
\hline & LB & $65 a$ & $72 a$ & $79 a$ & $92 \mathrm{a}$ & $55 \mathrm{a}$ & $12 \mathrm{a}$ \\
\hline \multirow[b]{2}{*}{ COMP } & $\mathrm{CV}$ & $8.4 \mathrm{a}$ & $7.9 b$ & $6.9 \mathrm{~b}$ & $7.2 \mathrm{~b}$ & $7.6 \mathrm{~b}$ & $6.7 b$ \\
\hline & LB & $8.4 \mathrm{a}$ & $12.5 \mathrm{a}$ & $8.8 \mathrm{a}$ & $10.2 \mathrm{a}$ & $8.9 a$ & $8.5 \mathrm{a}$ \\
\hline \multirow{2}{*}{ MSP } & $\mathrm{CV}$ & $0.50 \mathrm{a}$ & $0.34 \mathrm{~b}$ & $0.25 \mathrm{~b}$ & $0.26 \mathrm{~b}$ & $0.37 \mathrm{a}$ & $0.30 \mathrm{~b}$ \\
\hline & LB & $0.50 \mathrm{a}$ & $0.51 \mathrm{a}$ & $0.41 \mathrm{a}$ & $0.39 \mathrm{a}$ & $0.47 \mathrm{a}$ & $0.47 \mathrm{a}$ \\
\hline
\end{tabular}

Means followed by the same letter in the column are not statistically different from each other at $5 \%$ probability by Tukey test.

percentage $(95 \%)$, with increasing periods of desiccation reducing the number of germinated seeds. This effect was more pronounced ( $80 \%$ germination) in seeds that were dried in greenhouse conditions for 48 hours, with final water content being $12.33 \%$ (Figure 2A). With the exception of the zero period, in the remaining periods there was significant difference in germination between the two drying environment being lower when seeds were dried in the greenhouse (Table 1). According to BARBEDO \& MARCOSFILHO (1998), changes in the water content can define the behavior of seeds with regard to the conservation or germination.

Increase in the drying period caused a reduction in the seed moisture content and; consequently, the percentage of seedling emergence, when $C$. tapia seeds were dried in a greenhouse environment. The highest emergence level $(86 \%)$ was for the treatment of zero hours (no drying), which reduced to $67 \%$ after 120 hours of drying, with the water content at around $12 \%$. The data from drying seeds in a laboratory environment did not fit polynomial regression models, and reported an average emergence of $87 \%$ (Figure 2B). When comparing the two drying environments it has been found that the seeds were less affected by drying in a laboratory environment, once the mean emergence of seedlings obtained dry seeds in this environment were statistically superior, except at zero time (Table 2).

Reduction in seedling emergence for seeds dried in the greenhouse can be associated with more rapid loss of water types present in the layers of the seed, and the effects of drying in this environment evidenced the vigor. Therefore, it has been emphasized that sensitive seeds do not tolerate drying owing to the removal of water associated with their structure, which is essential for maintaining cell integrity (MARCOS-FILHO, 2015).

It is also known that the loss of water in some recalcitrant seeds initiates deteriorative processes, such as denaturation of proteins, alterations in the activity of peroxidase enzymes, and damage to the membrane system, resulting in a complete loss of viability (NAUTIYAL \& PUROHIT, 1985).

Regarding the water content, VILLELA \& MARCOS-FILHO (1998) reported that there are five types in seeds: water type 1, which are present in very dry tissue and strongly associated with macromolecules by ionic bonds; water type 2, with 7.5 to $20 \%$ moisture and linked to macromolecules via hydrogen bonds; water type 3 , with water content of 20 to $33 \%$ and associated with hydrophobic sites 
Table 2 - Water content (TA), seedling emergence (E), speed indices of seedling emergence (IVE), first counts of seedling emergence (PC), length (COMP) and dry mass (MSP) of Crataeva tapia L. seedlings from emergence tests after drying in greenhouse (CV) and lab environment (LB).

\begin{tabular}{|c|c|c|c|c|c|c|c|}
\hline \multirow{2}{*}{ Variables } & \multirow{2}{*}{ Drying environments } & \multicolumn{6}{|c|}{-----------------------------------------Drying times--------------------------------------. } \\
\hline & & 0 & 24 & 48 & 72 & 96 & 120 \\
\hline \multirow[b]{2}{*}{ TA $(\%)$} & $\mathrm{CV}$ & $35.9 \mathrm{a}$ & $18.5 \mathrm{a}$ & $11.4 \mathrm{a}$ & $9.4 \mathrm{a}$ & $9.2 b$ & $10.0 \mathrm{~b}$ \\
\hline & LB & $35.9 \mathrm{a}$ & $14.9 \mathrm{~b}$ & $11.3 \mathrm{a}$ & $9.6 \mathrm{a}$ & $10.0 \mathrm{a}$ & $10.9 \mathrm{a}$ \\
\hline \multirow[b]{2}{*}{$\mathrm{E}(\%)$} & $\mathrm{CV}$ & $90 a$ & $81 b$ & $78 b$ & $69 b$ & $74 b$ & $70 \mathrm{~b}$ \\
\hline & LB & $90 \mathrm{a}$ & $91 \mathrm{a}$ & $84 a$ & $95 a$ & $87 \mathrm{a}$ & $78 \mathrm{a}$ \\
\hline \multirow[b]{2}{*}{ IVE } & $\mathrm{CV}$ & $1.7 \mathrm{a}$ & $1.4 \mathrm{~b}$ & $1.1 \mathrm{~b}$ & $1 b$ & $1 \mathrm{a}$ & $1 \mathrm{a}$ \\
\hline & LB & $1.7 \mathrm{a}$ & $1.8 \mathrm{a}$ & $1.3 \mathrm{a}$ & $1,3 \mathrm{a}$ & $1 \mathrm{a}$ & $1 \mathrm{a}$ \\
\hline \multirow[b]{2}{*}{ PC } & $\mathrm{CV}$ & $53 a$ & $15 b$ & $0 \mathrm{a}$ & $0 \mathrm{a}$ & $0 \mathrm{a}$ & $0 \mathrm{a}$ \\
\hline & LB & $53 a$ & $18 \mathrm{a}$ & $0 \mathrm{a}$ & $0 \mathrm{a}$ & $0 \mathrm{a}$ & $0 \mathrm{a}$ \\
\hline \multirow[b]{2}{*}{ COMP } & $\mathrm{CV}$ & $13.2 \mathrm{a}$ & $11 \mathrm{~b}$ & $12 b$ & $12 \mathrm{a}$ & $12 \mathrm{a}$ & $14.7 \mathrm{~b}$ \\
\hline & LB & $13.2 \mathrm{a}$ & $13 a$ & $15 \mathrm{a}$ & $12 a$ & $12 \mathrm{a}$ & $16 \mathrm{a}$ \\
\hline \multirow{2}{*}{ MSP } & $\mathrm{CV}$ & $1.26 \mathrm{a}$ & $0.93 b$ & $0.63 b$ & $0.46 \mathrm{~b}$ & $0.57 b$ & $0.81 \mathrm{~b}$ \\
\hline & LB & $1.26 \mathrm{a}$ & $1.36 \mathrm{a}$ & $1.03 \mathrm{a}$ & $0.75 a$ & $0.93 a$ & $1.14 \mathrm{a}$ \\
\hline
\end{tabular}

Means followed by the same letter in the column are not statistically different from each other at $5 \%$ probability by Tukey test.

of macromolecules for forming bridges; water types 4 and 5, which fill small spaces in the cell solution, and do not interact with proteins.

Water loss from seeds can cause various types of injuries, for example, physical ones that are associated with reduction in the cell volume, which is important in many tissues for hydration and in cells with large vacuoles. Another type of injury is uncoordinated metabolism, when the predominant water type is 3 or 4 , involving degradation mediated by free radicals. The removal of water associated with macromolecule surfaces is necessary to maintain the integrity of cellular structures as it can cause severe damage, especially in tissues undergoing very fast drying (MARCOS-FILHO, 2015).

During the drying process, loss of water in desiccation-intolerant seeds incurs several metabolic costs (PAMMENTER \& BERJAK, 2000). However, we reported that the drying temperature also contributed to reduction in seed vigor, as the seeds dried in the greenhouse environment at around $30^{\circ} \mathrm{C}$ had their vigor reduced, while those dried at $25^{\circ} \mathrm{C}$ in laboratory environment did not exhibit a reduction in seedling emergence.

Temperature is a factor that needs to be considered during drying, because elevated temperatures can cause physiological damage, reflecting changes in the subcellular systems including chromosomes and mitochondria, such as reducing the number of starch granules in the embryonic axis, which increases the leaching of electrolytes (GARCIA et al., 2004).

The susceptibility of seeds toward physiological damage during drying depends on the species, genotype, water content, temperature, exposure time, and drying speed (GARCIA et al., 2004). For the seeds of Inga laurina (Sw.) Willd., drying performed in a greenhouse affects the vigor, causing reductions in seedling emergence (BARROZO et al., 2014). For the seeds of Talisia esculenta Radlk dried at different controlled temperatures $\left(40,45\right.$, and $\left.50^{\circ} \mathrm{C}\right)$ it was reported that the temperature of $50^{\circ} \mathrm{C}$ was most damaging to the vigor of the seeds (CARDOSO et al., 2015).

Water content is a determinant of the behavior of seeds during storage; however, the sensitivity of recalcitrant seeds toward drying depends on the species being critical and lethal levels of relatively high water (ANDRADE \& PEREIRA, 1997). GEMAQUE et al. (2005) stated that there are indications that the minimum water content that can be harmful and lead to loss of viability in recalcitrant seeds is highly variable within and across species. In Cinnamomum zeylanicum Ness seeds, for example, the period of desiccation tolerance was 12 hours, corresponding 


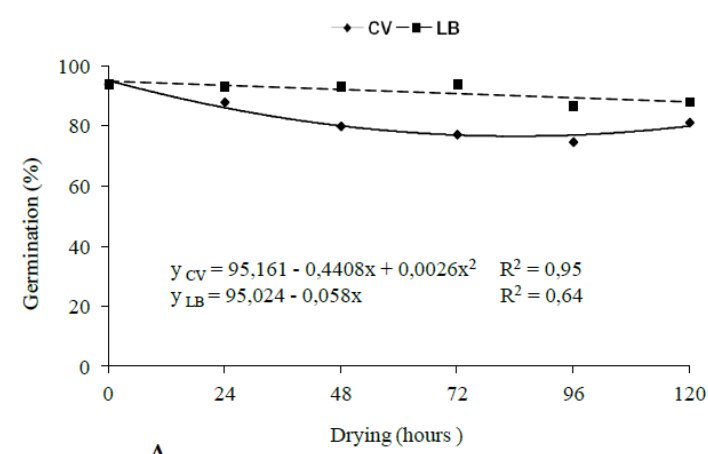

A

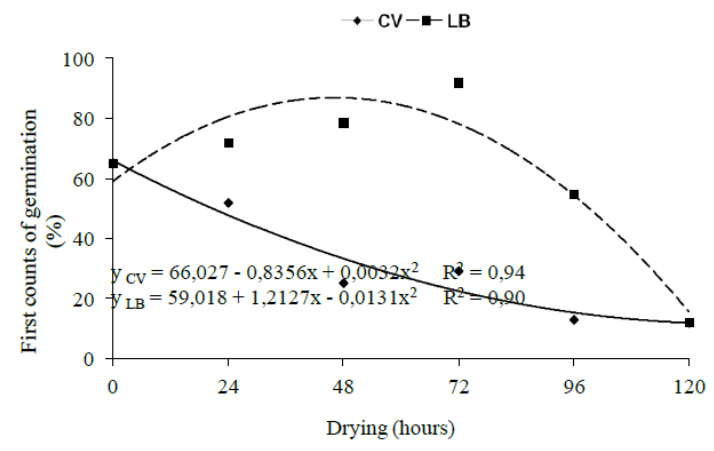

$\mathrm{C}$

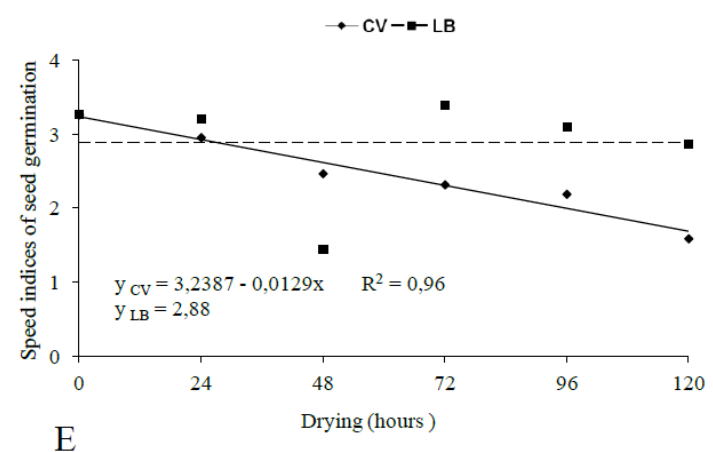

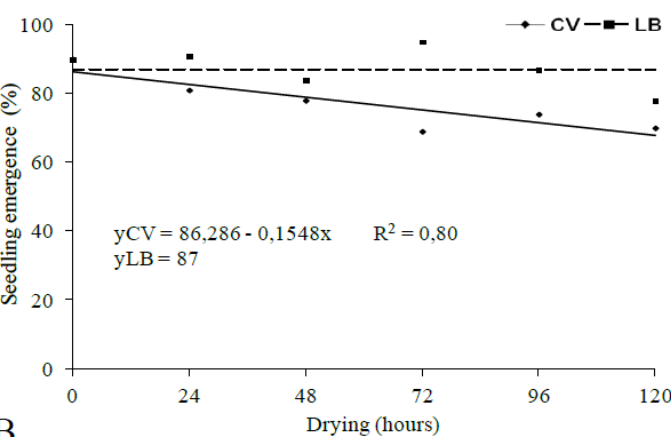

$\mathrm{B}$
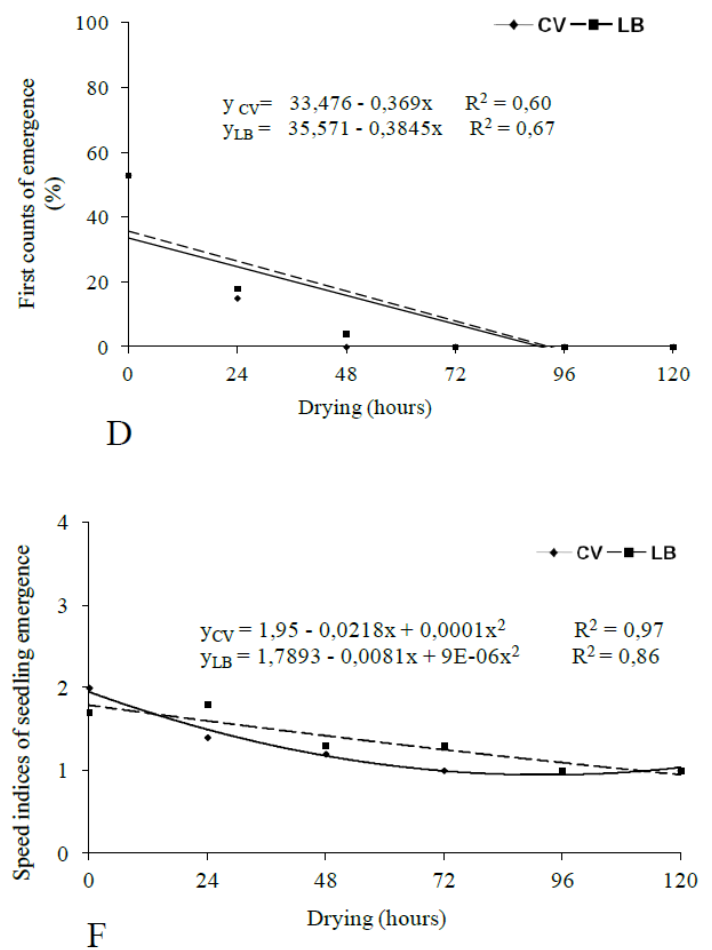

F

Figure 2 - Germination (A), seedling emergence (B), first counts of germination (C) and seedling emergence (D), speed indices of seed germination $(\mathrm{E})$ and seedling emergence $(\mathrm{F})$ in Crataeva tapia L., as a response to drying in greenhouse $(\mathrm{CV})$ and lab environment (LB). ${ }^{* *} \mathrm{P}<0.01,{ }^{*} \mathrm{P}<0.05$.

to a humidity level of $34.82 \%$, and the germination and emergence levels decreased with dehydration (SILVA et al., 2012).

As for the vigor determined by first count (Figure 2C), the number of germinated seeds decreased with increasing drying periods, and the effect was more pronounced for the seeds dried in greenhouse. The maximum observed value $(66 \%)$ of vigor was low for the period zero (no drying). However, with increasing drying time, it tended to reduce linearly and fell to $12 \%$. For the seeds dried in laboratory, reduction in water content within the first 24 hours resulted in an increase in germination, which reached $87 \%$ at 48 hours. Similar results were obtained by SANTOS-MOURA et al. (2012), whose first count of T. guianensis Aublet seeds was sensitive enough to detect changes in vigor after 3 hours of drying. The first count seed germination in the greenhouse was similar to the values obtained in the laboratory only in zero time and 120 hours of drying, in other periods there was statistical difference between the two drying environment (Table 1). 
The first count for emergence reported significant reductions in the first few hours of drying in both environments, registering the highest emergence percentage at zero period, which became null after 48 hours (Figure 2D and Table 2). Results indicated that $C$. tapia seeds showed an intermediate behavior in response to moisture loss, as the vigor was reduced when the water content reached $12.33 \%$, especially in seeds that were dried in greenhouse. Such seeds, which tolerate desiccation at water content of $10-13 \%$ and have limited viability at lower levels, are classified as intermediate, according to FONSECA \& FREIRE (2003).

Unlike $C$. tapia, the seeds of Talisia esculenta Radlk are considered recalcitrant, as they remain viable even after 120 hours of drying at the first count of emergence, emphasizing that the seed behavior upon drying varies among species (ALVES et al., 2008).

The highest germination speed index for the $C$. tapia seeds dried in greenhouse environment was obtained at 0 hours of drying time (3.23), and it decreased linearly with increasing drying periods. For seeds dried in laboratory environment, the data did not fit polynomial regression models, and had a mean value of 2.88 , demonstrating that drying in laboratory environment is less damaging to the seed quality than greenhouse drying (Figure 2E). Difference were reported in germination speed index when the seeds were dried in a greenhouse with 72 hours of drying, whose values were lower than those obtained in laboratory environment (Table 1).

It was observed that the emergence speed index reduced with increasing drying periods in both environments, with statistically values minors in periods of 24 to 72 hours of drying in greenhouse (Table 2). The most marked reduction was for seeds drying in greenhouse, which had noticeable reductions within the first few hours of drying (Figure 2F). The highest values were obtained for the zero period, in both the environments. The reduction in seed vigor as a result of drying is probably due to the membrane systems getting affected (BARROS et al., 2010), which is also reflected in the physiological condition of Cinnamomum zeylanicum Ness seeds, and is evident within the first 12 hours of drying (SILVA et al., 2012).

Data for seedling lengths from the germination and emergence tests (Figures $3 \mathrm{~A}$ and $3 \mathrm{C}$ ) conducted in laboratory environment did not fit polynomial regression models, and had average values of 9.5 and $13 \mathrm{~cm}$ respectively, indicating feeble influence of drying on this variable.

For greenhouse drying, the length of seedlings from germination test reduced linearly with increasing drying period (Figure 3A); whereas, the seedling lengths from the emergence test showed a reduction from $12.9 \mathrm{~cm}$ at period zero to $11.15 \mathrm{~cm}$ at 48 hours, after which increased as a function of drying time (Figure 2C). This behavior is likely to be related to the increased water content recorded in the same period, as it may have contributed to the activation of enzymes related to the germinal metabolism, which were otherwise disabled at low water content.

For the dry mass of C. Tapia seedlings from germination test, no significant variations were noted with increasing drying time in laboratory environment, and a mean value of $0.46 \mathrm{~g}$ was obtained. For seeds drying in greenhouse environment, the data were adjusted to the polynomial regression model. The highest value $(0.47 \mathrm{~g})$ was observed at 0 hours of drying time, and it reduced to $0.36 \mathrm{~g}$ after the longest period of drying (Figure 3B).

For all variables, including the dry mass of seedlings during the emergence test, the highest values were observed at 0 hours of drying time in both environments, and a significant reduction was seen with increasing drying time. This decrease was more drastic in the seedlings that were derived from the seeds dried in the greenhouse environment (Figure 3D). Although, relatively higher dry matter content was observed in seedlings from the emergence test, certainly due to the longer lengths of them, since the paper substrate seedling growth is limited due to the space between the seed and also because of the way the substrate is kept in roll format.

Length of seedlings from the germination of seeds that were not subjected to drying were statistically similar in both environments, but after 24 hours of drying was no difference in mean length of seedlings from seeds subjected in a greenhouse environment being lower than those obtained seeds dried in laboratory environment, while the average length of seedlings from the emergency were statistically lower than when the seeds were dried at glasshouse ambient periods of 24, 48 and 120 hours. Conversely, the dry mass of seedlings arising both germination and emergence was statistically lower when the seeds were submitted to drying in greenhouse environment after 24 hours (Table 1 and 2).

The seed vigor decreased with increasing drying periods, and the vigor tests were sensitive enough to detect degenerative changes in seeds, which were not detected by the germination test. Similar results have been reported for T. esculenta Radlk, where extended periods of drying damaged the seed vigor, observed as significant reductions in the emergence first count, length, and seedling dry weight (ALVES et al., 2008). 


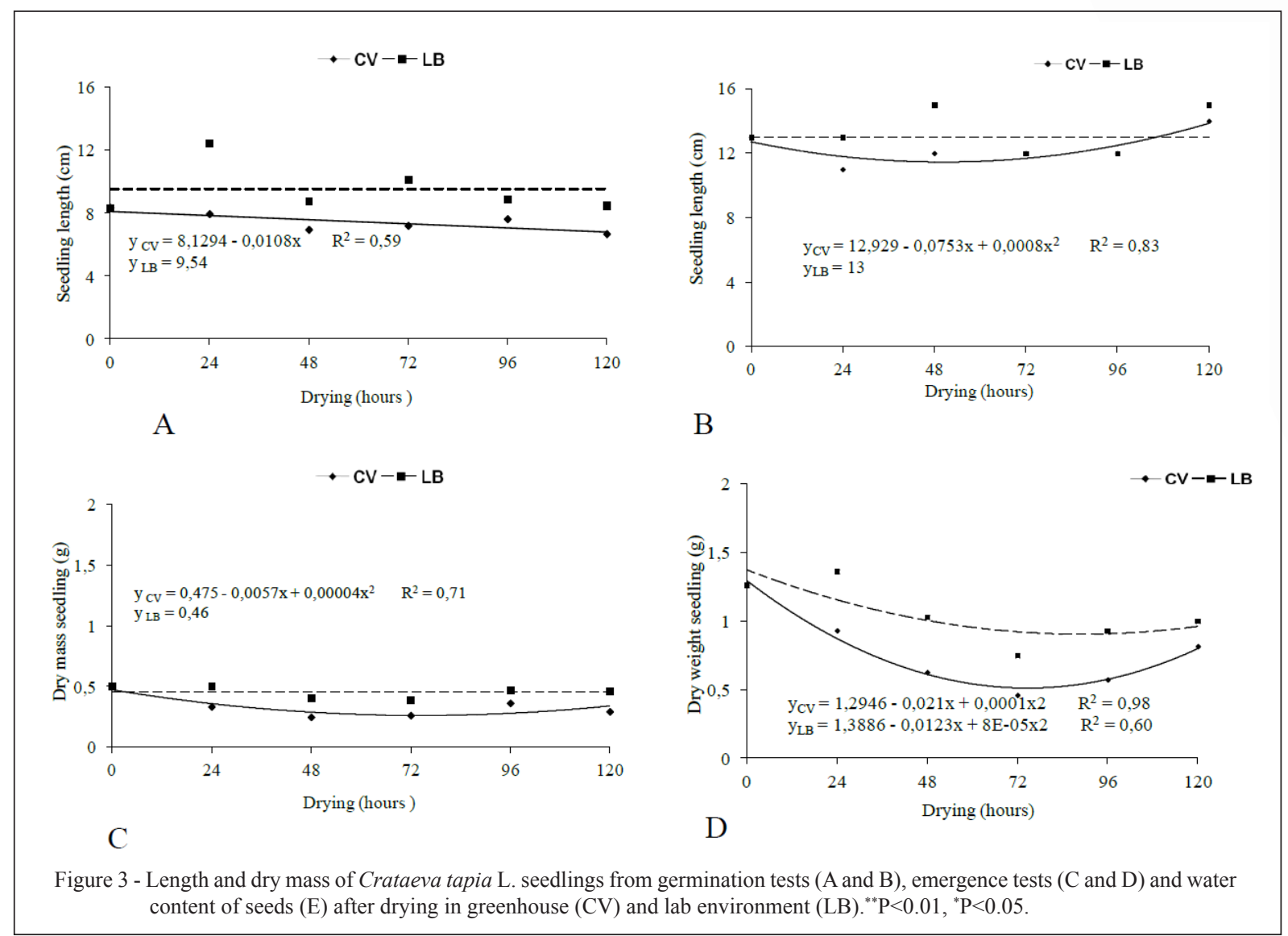

\section{CONCLUSION}

Seeds of $C$. tapia $\mathrm{L}$. are not tolerant to dehydration, especially when the drying is carried out in a greenhouse $\left(30^{\circ} \mathrm{C}\right.$ and $\left.80 \% \mathrm{RH}\right)$. Drying under these conditions reduces both the germination and seed vigor.

Seeds of C. Tapia may be dried at room temperature $\left(25^{\circ} \mathrm{C}\right.$ and $\left.90 \% \mathrm{RH}\right)$ for a period of 48 hours, and based on the drying response, they are classified as intermediate.

\section{REFERENCES}

ALVES, E.U. et al. Physiological behavior of pitombeira seeds [Talisia esculenta (A. ST. Hil) Radlk] submitted to dehydration. Revista Brasileira de Fruticultura, v.30, n.2, p.509-516, 2008. Available from: <http://dx.doi.org/10.1590/S0100-29452008000200042>. Accessed: Dec. 20, 2014

ALVES, E.U. et al. Germination and vigor of Crataeva tapia $\mathrm{L}$ seeds on different substrates and temperatures. Revista Brasileira de Fruticultura, v.34, n.4, p.1208-1215, 2012. Available from: $<$ http://www.scielo.br/scielo.php?script=sci_arttext\&pid $=\mathrm{S} 0100=29452012000400030-\& \operatorname{lng}=\mathrm{pt} \& \mathrm{nrm}=\mathrm{i}$ so \& $\mathrm{tlng}$ pt>. Accessed: Oct. 08, 2015.
ANDRADE, A.C.S.; PEREIRA, T.S. Storage behavior of palm tree (Euterpe edulis Mart.) seeds. Pesquisa Agropecuária Brasileira, v.32, n.10, p.987-991, 1997. Available from: <http://www.alice. cnptia.embrapa.br/bitstream/doc >. Accessed: Jan. 02, 2014.

BARBEDO, C.J.; MARCOS-FILHO, J. Seed desiccation tolerance. Acta Botanica Brasilica, v.12, n.2, p.145-164, 1998. Available from: <http://www.scielo.br/pdf/abb/v12n2/v12n2a05.pdf $>$. Acesso em: 2 jan. 2014.

BARROS, D.I. et al. Physiological behavior of mangaba seeds submitted to desiccation. Revista Acta Tecnológica, v.5, n.1, p.3143, 2010. Available from: <file:///D:/Downloads/19-67-1-PB.pdf>. Accessed: Feb. 22, 2014.

BARROZO, L.M. et al. Physiological quality of inga seeds due to drying. Bioscience Journal, v.30, n.3, p.645-654, 2014. Available from: <http://www.seer.ufu.br/index.php/biosciencejournal/issue/ archive>. Accessed: Oct. 06, 2015.

BRASIL. Ministério da Agricultura, Pecuária e Abastecimento. Rules for seed analysis. Secretaria de Defesa Agropecuária. Brasília: MAPA/ACS, 2009. 395p.

CARDOSO, E.A. et al. Pitombeira seeds quality of according to the period and the drying temperature. Semina: Ciências Agrárias, v.36, n.1, p.7-16, 2015. Available from: <HTTP://www.uel.br/revistas/uel/ index.php/semagrarias/article/view/11303>. Accessed: Oct. 08, 2015. 
CARVALHO, N.M. Seed drying. 2.ed. Jaboticabal: FUNEP, 2005. 184p.

FONSECA, S.C.L.; FREIRE, H.B. Recalcitrant seeds: post-harvest problems. Bragantia, v.62, n.2, p.297-303, 2003. Available from: $<$ http://www.scielo.br/pdf/brag/v62n2/v62n2a16.pdf $>$. Accessed: Feb. 22, 2014.

GALINDO, E.A. Seed Technology of Crataeva tapia L. 2010. $92 \mathrm{f}$. Dissertação (Mestrado em Agronomia) - Universidade Federal da Paraíba, Areia, PB. Available from: <http://www.ppgacca.com.br/ images/arquivos/pdf/dissertacao/235.pdf $>$. Accessed: Oct. 11, 2015.

GALINDO, E.A. et al. Germination and vigor of Crataeva tapia $\mathbf{L}$. seeds at different temperatures and light conditions. Revista Ciência Agronômica, v.43, n.1, p.138-145, 2012. Available from: <http://www.scielo.br/scielo. php?script=sci_arttext\&pid=S1806-66902012000100017\&lng-pt\&nrm=iso \&tlng-pt>. Accessed: Oct. 11, 2015.

GARCIA, D.C. et al. Seed drying. Ciência Rural, v.34, n.2, p.603608, 2004. Available from: <http://dx.doi.org/10.1590/S010384782004000200045>. Accessed: Mar. 14, 2014.

GEMAQUE, R.C.R. et al. Effect of slow and fast drying on ipêroxo seeds (Tabebuia impetiginosa (Mart.) Standl. Cerne, v.11, n.4, p.329-335, 2005. Available from: <http://www.redalyc.org/ pdf/744/74411402.pdf>. Accessed: Mar. 22, 2014.

HONG, T.D.; ELLIS, R.H. A protocol to determine seed storage behavior. In: ENGELS, J.M.M.; TOLL, J. Rome: IPGRI, 1996.b 62p. (IPGRI Technical Bulletin n.1). Available from: <https:// www.google.com.br/?gws $\mathrm{rd}=\mathrm{ssl} \# \mathrm{q}=\mathrm{A}+$ protocol+to + determine $+\mathrm{s}$ eed+storage+behavior>. Accessed: Oct. 11, 2015.

LORENZI, H. Brazilian trees: identification and cultivation of native tree plants in Brazil. 5.ed. Nova Odessa: Instituto Plantarum, 2009. 384p.

MAGUIRE, J.D. Speed of germination-aid in selection and evaluation for seedling emergence and vigor. Crop Science, v.2, n.2, p.176-177, 1962.

MARCOS-FILHO, J. Seed physiology of cultivated plants. ABRATES: Londrina, 2015. 659p.

NASCIMENTO, W.M.O. et al. Physiological consequences of desiccation in açaí seeds (Euterpe oleracea Mart.). Revista Brasileira de Sementes, v.29, n.2, p.38-43, 2007. Available from: $<\mathrm{http} / / \mathrm{dx}$.doi. org/10.1590/S0101-31222007000200006>. Accessed: Aug. 07, 2014.

NAUTIYAL, A.R.; PUROHIT, A.N. Seed viability in sal. II. Physiological and biochemical aspects of ageing in seeds of Shorea robusta. Seed Science and Technology, v.13, n.1, p.69-76, 1985.
PAMMENTER, N.W.; BERJAK, P. Aspects of recalcitrant seed physiology. Revista Brasileira de Fisiologia Vegetal, v.12, n.Esp, p.56-69, 2000. <http://www.cnpdia.embrapa.br/rbfv/pdfs/ v12Especialp56.pdf>. Accessed: Ago. 01, 2014.

PEREIRA, W.V.S. et al. Desiccation tolerance of Tapirira obtusa seeds collected from different environments. Revista Brasileira de Sementes, v.34, n.3, p.388-396, 2012. Available from: <http:// dx.doi.org/10.1590/S0101-31222012000300005>. Accessed: Ago. 10,2014

REGO, S.S. Tolerance to dehydration and storage of seeds of Blepharocalyx salicifolius (Kunth) Berg. And Casearia decandra Jacq. 2012. 142f. Tese (Doutorado em Engenharia Florestal) Universidade Federal do Paraná, Curitiba, PR. Available from: <http://www.floresta.ufpr.br/pos-graduacao/defesas/pdf_dr/2012/ t318_0197-D.pdf>. Accessed: Oct. 11, 2015.

ROBERTS,E.H.Predictingthestoragelifeofseeds.SeedScienceand Technology, v.1, n.4,p.499-514, 1973.Available from: $<$ http://www. scielo.br/scielo.php?script=sci_nlinks\&ref=000101\&pid=S0104$7760201400030001800019 \& \operatorname{lng}=\mathrm{en}>$. Accessed: Octt. 11, 2015.

SANTOS-MOURA, S.S. et al. Influence of different drying periods on the physiological quality of seeds of Tapirira guianensis Aublet. Revista Brasileira de Fruticultura, v.34, n.2, p.381389, 2012. Available from: <http://dx.doi.org/10.1590/S010029452012000200010>. Accessed: Nov. 15, 2014.

SANTOS-MOURA, S.S. et al. Physiological quality of seeds of Crataeva tapia L. submitted to different methods of extracting the mucilage. Revista Brasileira de Fruticultura, v.36, n.3, p.686-692, 2014. Available from: <http://www.scielo.br/scielo. php? pid $=$ S0100-29452014000300021\&script $=$ sci_arttext $>$. Accessed: Oct. 11, 2015.

SILVA, K.B. et al. Tolerance to desiccation of Cinnamomum zeylanicum Ness. of seeds. Semina: Ciências Agrárias, v.33, n.2, p.587-594, 2012. Available from: $<$ http://dx.doi.org/10.5433/16790359.2012v33n2p587>. Accessed: Nov. 15, 2014.

VILLELA, F.A.; MARCOS-FILHO, J. Energy states and water types in seed. Revista Brasileira de Sementes, v.20, n.2, p.79-83, 1998. Available from: <http://www.abrates.org. br/revista/artigos/1998/v20n2/artigo13.pdf >. Accessed: Feb. 26, 2016.

WALTERS, C. Levels of recalcitrance in seeds. Revista Brasileira de Fisiologia Vegetal, v.12, n.esp, p.721, 2000. Available from: $<\mathrm{http}: / / \mathrm{www}$.scielo.br/scielo php? script $=$ sci_nlinks \& ref $=000078 \&$ pid $=$ S 0100 2945201400040002900019\&lng=en>. Accessed: Oct. 11, 2015. 